\title{
EVALUATION AND MANAGEMENT OF DIFFICULT AIRWAY IN OBESITY: A SINGLE CENTER RETROSPECTIVE STUDY
}

\author{
Asude Ayhan, Serife Kaplan, Zeynep Kayhan and Gulnaz Arslan \\ Baskent University School of Medicine, Department of Anesthesiology and Reanimation, Ankara, Turkey
}

\begin{abstract}
SUMMARY - The primary aim of this single center retrospective study was to evaluate difficult mask ventilation (DMV) and difficult laryngoscopy (DL) in a unique group of obese patients. A total of 427 adult patients with body mass index (BMI) $\geq 25$ and surgically treated for endometrial cancer from 2011 to 2014 were assessed. Additional increase in BMI, comorbidities, bedside screening tests for risk factors, and the tools used to manage the patients were noted and their effects on DMV and/or DL investigated. Every escalation in the number of risk factors increased the probability of DMV 2.2-fold, DL 1.8-fold and DMV+DL 3.0-fold. Among bedside tests, limited neck movement (LNM), short neck (SN) and absence of teeth were significant for DMV ( $<<0.05), \mathrm{LNM}, \mathrm{SN}$ and obstructive sleep apnea for DL ( $<<0.05)$, and LNM and SN for DMV+DL $(\mathrm{p}<0.05)$. However, a 10 -point increase of BMI was not an independent risk factor when patients with BMI $>25 \%$ were considered. In conclusion, LNM and SN are independent risk factors for developing DMV and/or DL in obese endometrial cancer patients, while BMI increase over 30 was not additionally affecting difficult airway.
\end{abstract}

Key words: Airway Management; Airway Obstruction; Intubation, Intratracheal; Laryngoscopy; Endometrial Neoplasms - Surgery; Anesthesia, General; Obesity

\section{Introduction}

Obesity is excessive accumulation of adipose tissue in the body and is often classified according to the body mass index (BMI) as follows: $\mathrm{BMI} \geq 30 \mathrm{~kg} / \mathrm{m}^{2}$ as obese, BMI $\geq 40 \mathrm{~kg} / \mathrm{m}^{2}$ as morbidly obese, and BMI $\geq 50 \mathrm{~kg} / \mathrm{m}^{2}$ as super-obese ${ }^{1,2}$. The incidence of obesity has been dramatically increasing all over the world and approximately $13 \%$ of the world adult population were obese in $2014^{2}$.

Currently, anesthesiologists are progressively faced with care for obese patients. Obesity is known as an

Correspondence to: Asude Ayhan, MD, Baskent University School of Medicine, Department of Anesthesiology and Reanimation, Fevzi Cakmak Caddesi, 10. sokak, No. 45, 06490 Bahcelievler, Ankara, Turkey

E-mail: drocude@yahoo.com

Received March 10, 2015, accepted September 18, 2015 independent risk factor for the combination of difficult mask ventilation (DMV) with difficult laryngoscopy $(\mathrm{DL})^{3}$. Moreover, it has been accepted as a predictor for DMV, supraglottic device placement failure, and difficult emergency surgical airway ${ }^{4}$.

Endometrial cancer is the most common gynecologic cancer and obesity is one of the most important risk factors ${ }^{5}$. Furthermore, these patients present to the hospital with obesity-driven comorbidities, such as diabetes mellitus type 2 , hypertension, heart disease, and pulmonary disease ${ }^{5,6}$. So, the anesthetic management of those patients may remain challenging. While there are many reports comparing the anesthetic complications between obese and lean patients ${ }^{3-8}$, there is no report whether further increase in BMI has additional implication, and which bedside screening test is more meaningful for predicting DMV and DL when only obese group is considered. 
The aim of this study was to evaluate DMV and DL in this unique group of adult obese patients with endometrial cancer. The importance of bedside screening tests for risk factors, additional increase in BMI, and the effect of comorbidities for difficult airway management were examined.

\section{Material and Methods}

This single center retrospective study evaluated adult patients surgically treated for endometrial cancer from January 2011 to December 2014. After institutional reviewer board's approval [Baskent University Institutional Review Board (Project no: KA15/11)], a total of 600 files of patients operated for endometrial cancer were reviewed and only those patients with $\mathrm{BMI} \geq 25(\mathrm{~N}=427)$ were included in the study. These patients were further subdivided into overweight $(\geq 25>30)$, obese $(\geq 30>40)$, morbidly obese $(\geq 40>50)$ and super-obese $(\geq 50)$ groups.

Patient files and electronic hospital database were evaluated to identify patient demographic aspects and comorbid conditions (The American Society of Anesthesiologists Physical Status classification system [ASA], diabetes mellitus [DM], hypertension [HT], hyperlipidemia [HL], coronary artery disease [CAD], smoking, and goiter), and head and neck anatomical characteristics. Information on the risk factors determined by bedside screening tests including modified Mallampati oropharyngeal classification ${ }^{9}$, absence of teeth, limited mouth opening $(<3 \mathrm{~cm})$, limited neck movement and short neck, presence of dentures, and presence of obstructive sleep apnea (OSA) $)^{3,7}$ was collected from the routine standard form filled in by the anesthesiologists during preoperative visit and during induction of anesthesia. As our standard records also include reliable information concerning induction of anesthesia and mask ventilation difficulty rated by staff anesthesiologist in a standardized manner, we were able to classify patients into three separate groups with respect to difficulty in airway management as follows: DMV (Han's mask ventilation classification grade 3 or 4 mask ventilation) ${ }^{10}$; DL (grade 3 or 4 laryngoscopic view or $\geq 4$ intubation attempts) ${ }^{11}$; and DMV combined with DL. The techniques and tools (bougie, guide wire, laryngeal mask airway [LMA]) used to manage patients with difficult airway were noted. There was no missing report in these groups of patients.

\section{Statistical analysis}

Descriptive statistics was identified as means and standard deviations. Mann-Whitney U test was used to compare the groups for normal and non-normal variable distribution. The relationship between two categorical variables was determined by $\chi^{2}$-test. Multivariate logistic regression analysis was used to evaluate risk factors for DMV and DL. First, univariate analyses were performed to select candidate variables for logistic model. To get significant odds ratios for logistic model, type-I error rate was taken as $\alpha=0.05$. The level of statistical significance was set at $\mathrm{p}<0.05$. The IBM SPSS 21.0 (IBM Corp. Released 2012, IBM SPSS Statistics for Windows, Version 21.0, Armonk, NY, USA) was used on statistical analyses.

\section{Results}

A total of 427 consecutive adult patients, mean age $57.93 \pm 11.78$ years, were evaluated. The mean BMI value was $35.7 \pm 6.15 \mathrm{~kg} / \mathrm{m}^{2}$ and the distribution was as follows: overweight 18 (4.2\%); obese 320 (74.9\%); morbidly obese 74 (17.3\%); and super-obese 15 (3.6\%). There were 140 patients with DMV, 123 with DL, and 61 with DMV in combination with DL. The univariate analysis of demographic aspects and comorbidity risk factors recorded in the patients are shown in $\mathrm{Ta}^{-}$ ble 1. Statistical analysis revealed that weight, BMI, ASA score, presence of HT and HL were significant for DMV, DL, and DMV with DL. The presence of DM was significant only for DMV (Table 1). On the other hand, smoking and presence of goiter showed no correlation with DMV, DL, or both $(\mathrm{p}>0.05$, data not presented in Table 1).

Concerning bedside screening tests for risk factors and the auxiliary tools used to manage difficult airway, the univariate analysis revealed that Mallampati scores III and IV, limited neck movement and short neck were significantly associated with DMV, DL and DMV+DL, whereas the presence of sleep apnea was correlated with DMV+DL (Table 2). Guide wire was the most frequently used auxiliary tool to manage difficult airway in patients with DL, and DMV in combination with DL $(\mathrm{p}<0.001)$ in our institution during the study period (Table 2).

The impact of risk factors in these groups is summarized in Table 3 as the result of multivariate analy- 
Table 1. Patient demographic features and presence of clinical risk factors compared with their individual effects on difficult mask ventilation and difficult laryngoscopy (univariate analysis)

\begin{tabular}{|c|c|c|c|c|c|c|c|c|c|}
\hline & DMV & & DL & & $\begin{array}{l}\text { DMV with } \\
\text { DL }\end{array}$ & & & & \\
\hline $\begin{array}{l}\text { Demographic } \\
\text { characteristics }\end{array}$ & $\begin{array}{c}\text { Yes } \\
(n=140)\end{array}$ & $\begin{array}{c}\text { No } \\
(n=287)\end{array}$ & $\mathbf{p}$ & $\begin{array}{c}\text { Yes } \\
(n=123)\end{array}$ & $\begin{array}{c}\text { No } \\
(n=304)\end{array}$ & $\mathbf{p}$ & $\begin{array}{c}\text { Yes } \\
(n=61)\end{array}$ & $\begin{array}{c}\text { No } \\
(n=225)\end{array}$ & $\mathbf{p}$ \\
\hline $\begin{array}{l}\text { Age }[\text { years] } \\
\text { Mean } \pm \text { SD }\end{array}$ & $60.99 \pm 11.04$ & $56.44 \pm 11.85$ & 0.003 & $59.19 \pm 11.26$ & $57.42 \pm 11.96$ & 0.242 & $59.26 \pm 11.38$ & $55.70 \pm 11.94$ & 0.111 \\
\hline $\begin{array}{r}\text { Weight }[\mathrm{kg}] \\
\text { Mean } \pm S D\end{array}$ & $95.61 \pm 19.72$ & $85.38 \pm 14.20$ & $<0.001$ & $96.15 \pm 20.39$ & $85.73 \pm 14.23$ & $<0.001$ & $96.79 \pm 22.47$ & $82.58 \pm 11.41$ & $<0.001$ \\
\hline $\begin{array}{c}\mathrm{BMI}\left[\mathrm{kg} / \mathrm{m}^{2}\right] \\
\text { Mean } \pm \mathrm{SD}\end{array}$ & $38.32 \pm 6.75$ & $34.42 \pm 5.41$ & $<0.001$ & $38.21 \pm 6.96$ & $34.69 \pm 5.49$ & $<0.001$ & $38.23 \pm 7.37$ & $33.39 \pm 4.52$ & $<0.001$ \\
\hline \multicolumn{10}{|c|}{ Clinical risk factors } \\
\hline ASA [n (\%)] & & & $<0.001$ & & & 0.001 & & & 0.002 \\
\hline 1 & $19(13.6)$ & $94(32.8)$ & & $17(13.8)$ & $96(31.5)$ & & $9(14.8)$ & $86(38.2)$ & \\
\hline 2 & $113(80.7)$ & $189(65.9)$ & & $103(83.8)$ & $199(65.5)$ & & $50(82.0)$ & $136(60.5)$ & \\
\hline 3 & $8(5.7)$ & $4(1.3)$ & & $3(2.4)$ & $9(3.0)$ & & $2(3.2)$ & $3(1.3)$ & \\
\hline $\mathrm{HT}[\mathrm{n}(\%)]$ & $101(72.1)$ & $156(54.4)$ & $<0.001$ & $88(71.5)$ & $169(55.6)$ & 0.002 & $41(67.2)$ & $109(48.4)$ & 0.009 \\
\hline HL [n (\%)] & $96(68.6)$ & $123(42.9)$ & $<0.001$ & $87(70.7)$ & $132(43.4)$ & $<0.001$ & $45(73.8)$ & $81(36.0)$ & $<0.001$ \\
\hline $\mathrm{DM}[\mathrm{n}(\%)]$ & $67(47.9)$ & $92(32.1)$ & 0.002 & $54(43.9)$ & $105(34.5)$ & 0.070 & $25(41.0)$ & $63(28.0)$ & $0.073^{1}$ \\
\hline $\mathrm{CAD}[\mathrm{n}(\%)]$ & $15(10.7)$ & $17(5.9)$ & $0.117^{1}$ & $14(11.4)$ & $18(5.9)$ & $0.082^{1}$ & $8(13.1)$ & $11(4.9)$ & $0.037^{2}$ \\
\hline
\end{tabular}

${ }^{1}$ Continuity correction

${ }^{2}$ Fisher exact test

ASA = American Society of Anesthesiologists classification; $\mathrm{BMI}=$ body mass index $\mathrm{CAD}=$ coronary artery disease; $\mathrm{DM}=$ diabetes mellitus; DMV = difficult mask ventilation; DL = difficult laryngoscopy; HT = hypertension; HL = hyperlipidemia

sis. Every ten-point increase in BMI was not found to be an independent risk factor when patients with BMI $>25 \%$ were considered. However, when all the analyzed factors including BMI were sorted, we found that every escalation in the number of risk factors increased the probability of DMV 2.25-fold (CI: [1.862.72]), DL 1.84-fold (CI: [1.54-2.19]) and DMV+DL 3.04-fold (CI: [2.24-4.13]).

\section{Discussion}

This study aimed to analyze the difficult airway conditions in a group of obese adult patients with endometrial cancer and to identify the risk factors for difficult airway management in such a group of patients. Obesity is a well known but alone not sensitive enough predictor of airway management. When we examined whether further increase in BMI had additional implication when only obese group was considered, we found no statistical significance of increasing BMI in the high BMI group (Table 3) for difficult airway management. When we examined which bedside screening test was more meaningful for predicting DMV and DL, LNM and SN were found to be the most important major risk factors for DMV, DL, and DMV in combination with DL.

In our cohort, the incidence of DMV, DL, and DMV in combination with DL was higher than those reported in the literature ${ }^{3,12}$. This might be because of the lack of standard criteria to describe DMV and/or $\mathrm{DL}^{3,12}$, as well as for the selected patient cohort being composed of endometrial cancer patients with a mean age of $57.93 \pm 11.78$ years and mean $B M I$ value 
Table 2. Comparison of the effect of bedside screening tests and auxiliary tools used to manage difficult airway on difficult mask ventilation and difficult laryngoscopy (univariate analysis)

\begin{tabular}{|c|c|c|c|c|c|c|c|c|c|}
\hline & \multicolumn{2}{|c|}{ DMV } & & \multicolumn{2}{|c|}{ DL } & & \multicolumn{2}{|c|}{ DMV with DL } & \multirow[b]{2}{*}{$\mathbf{p}$} \\
\hline $\begin{array}{l}\text { Bedside screening } \\
\text { tests risk factors } \\
\text { [n (\%)] }\end{array}$ & $\begin{array}{c}\text { Yes } \\
(\mathbf{n}=140)\end{array}$ & $\begin{array}{c}\text { No } \\
(\mathbf{n}=287)\end{array}$ & $\mathbf{p}$ & $\begin{array}{c}\text { Yes } \\
(\mathrm{n}=123)\end{array}$ & $\begin{array}{c}\text { No } \\
(n=304)\end{array}$ & $\mathbf{p}$ & $\begin{array}{c}\text { Yes } \\
(n=61)\end{array}$ & $\begin{array}{c}\text { No } \\
(\mathrm{n}=225)\end{array}$ & \\
\hline $\begin{array}{l}\text { Mallampati } \\
\text { III or IV }\end{array}$ & $38(27.1)$ & $35(12.2)$ & $<0.001^{1}$ & $31(25.2)$ & $42(13.8)$ & $0.007^{1}$ & $12(19.7)$ & $16(7.1)$ & $0.007^{1}$ \\
\hline Absence of teeth & $30(21.4)$ & $21(7.3)$ & $<0.001^{1}$ & 18 (14.6) & $33(10.9)$ & $0.355^{1}$ & $9(14.8)$ & $12(5.3)$ & $0.023^{2}$ \\
\hline $\begin{array}{l}\text { Limited mouth } \\
\text { opening }\end{array}$ & $18(12.9)$ & $12(4.2)$ & $0.002^{1}$ & $12(9.8)$ & $18(5.9)$ & $0.232^{1}$ & $4(6.6)$ & $4(1.8)$ & $0.067^{2}$ \\
\hline $\begin{array}{l}\text { Limited neck } \\
\text { movement }\end{array}$ & $74(52.9)$ & 49 (17.1) & $<0.001$ & $63(51.2)$ & $60(19.7)$ & $<0.001$ & $35(57.4)$ & $21(9.3)$ & $<0.001^{1}$ \\
\hline Short neck & $60(42.9)$ & $43(15.0)$ & $<0.001$ & $52(42.3)$ & $51(16.8)$ & $<0.001$ & $31(50.8)$ & $22(9.8)$ & $<0.001^{1}$ \\
\hline Sleep apnea & $15(10.7)$ & $9(3.1)$ & $0.003^{1}$ & $17(13.8)$ & $7(2.3)$ & $<0.001^{1}$ & $8(13.1)$ & $0(0.0)$ & - \\
\hline \multicolumn{10}{|l|}{ Tools [n (\%)] } \\
\hline Bougie & $19(13.6)$ & $21(7.3)$ & $0.057^{1}$ & $40(32.5)$ & $0(0.0)$ & - & $19(31.1)$ & $0(0.0)$ & - \\
\hline Guide wire & $49(35.0)$ & $52(18.1)$ & $<0.001$ & $99(80.5)$ & $0(0.0)$ & $<0.001$ & $49(80.3)$ & $2(0.9)$ & $<0.001^{1}$ \\
\hline LMA & $2(1.4)$ & $3(1.0)$ & $0.665^{2}$ & $5(4.1)$ & $0(0.0)$ & - & $2(3.3)$ & $0(0.0)$ & - \\
\hline
\end{tabular}

${ }^{1}$ Continuity correction

${ }^{2}$ Fisher exact test

DMV = difficult mask ventilation; DL = difficult laryngoscopy; LMA = laryngeal mask airway

of $35.7 \pm 6.15 \mathrm{~kg} / \mathrm{m}^{2}$, slightly different from previously reported.

We were unable to identify the effect of BMI on difficult airway. Recent studies have demonstrated that a BMI of more than $30 \mathrm{~kg} / \mathrm{m}^{2}$ is an independent risk factor for DMV in combination with $\mathrm{DL}^{3}$. In addition, age ( $\geq 46$ years), male gender, limited thyromental distance, Mallampati class III or IV, presence of beard, OSA, presence of teeth, unstable cervical spine-limited neck extension, limited jaw protrusion, thick neck, neck radiation and limited mouth opening were also shown to be predictors of DMV in combination with $\mathrm{DL}^{3}$. Age ( $>55$ years), BMI $\left(>26 \mathrm{~kg} / \mathrm{m}^{2}\right)$, lack of teeth, history of snoring, male gender, presence of beard and Mallampati class IV are reported to be predictors of $\mathrm{DMV}^{12-14}$. In a cohort of 91332 patients, Lundstrom et al. found that Mallampati class III or IV, male gender, age, surgical priority, previous difficult intubation, no relaxation with neuromuscular blocking agent and BMI $(25 \leq \mathrm{BMI}<35$ and $\geq 35 \mathrm{~kg} /$ $\mathrm{m}^{2}$ ) were predictors of difficult intubation ${ }^{15}$.
Literature reports have suggested the use of bougie introducer, flexible fiberoptic bronchoscope, video laryngoscope and LMA as rescue techniques in the management of challenging airway situations ${ }^{3}$. In the present study, the main tools to manage difficult airway were guide wire and bougie. LMA was used in a limited number of cases and no other tools/instruments were utilized. As this was a retrospective study covering 5 years and there was no video laryngoscopy at our hospital during the study period, there was no attempt to mention video laryngoscopy for study patients.

There were several limitations to the current study. The retrospective nature of data analysis limited establishment of causal relationship for the associations. Our data come from a single center and results are based only on female gender, as well as on a specific type of disease that has both advantages and disadvantages, the latter especially limiting generalization of the results obtained. On the other hand, disease specific registries offer an opportunity to analyze a substantially larger number of patients and condi- 
Table 3. Risk factors in predicting difficult mask ventilation, difficult laryngoscopy and difficult mask ventilation in combination with difficult laryngoscopy (multivariate logistic regression analysis)

\begin{tabular}{|c|c|c|c|c|c|c|}
\hline & \multicolumn{2}{|c|}{ DMV } & \multicolumn{2}{|r|}{ DL } & \multicolumn{2}{|c|}{ DMV combined with DL } \\
\hline & $\mathbf{p}$ & $\begin{array}{c}\text { OR } \\
(95 \% \mathrm{CI})\end{array}$ & $\mathbf{p}$ & $\begin{array}{c}\text { OR } \\
(95 \% \mathrm{CI})\end{array}$ & $\mathbf{p}$ & $\begin{array}{c}\text { OR } \\
(95 \% \mathrm{CI})\end{array}$ \\
\hline Number of risks & $<0.001$ & $\begin{array}{c}2.24 \\
(1.86-2.71) \\
\end{array}$ & $<0.001$ & $\begin{array}{c}1.83 \\
(1.54-2.19) \\
\end{array}$ & $<0.001$ & $\begin{array}{c}3.03 \\
(2.23-4.13) \\
\end{array}$ \\
\hline Constant & $<0.001$ & 0.06 & $<0.001$ & 0.08 & $<0.001$ & 0.02 \\
\hline BMI (per 10 units) & 0.40 & $\begin{array}{c}1.21 \\
(0.76-1.66) \\
\end{array}$ & 0.69 & $\begin{array}{c}1.09 \\
(0.70-1.68) \\
\end{array}$ & 0.249 & $\begin{array}{c}1.51 \\
(0.74-3.08) \\
\end{array}$ \\
\hline Obstructive sleep apnea & 0.35 & $\begin{array}{c}1.55 \\
(0.60-4.02) \\
\end{array}$ & 0.011 & $\begin{array}{c}3.55 \\
(1.34-9.41)\end{array}$ & $\mathrm{n} / \mathrm{a}$ & $\mathrm{n} / \mathrm{a}$ \\
\hline Limited mouth opening & 0.20 & $\begin{array}{c}1.78 \\
(0.72-4.35)\end{array}$ & 0.93 & $\begin{array}{c}0.96 \\
(0.39-2.33)\end{array}$ & 0.479 & $\begin{array}{c}1.87 \\
(0.32-10.74)\end{array}$ \\
\hline Limited neck movement & $<0.001$ & $\begin{array}{c}5.49 \\
(2.94-10.23) \\
\end{array}$ & $<0.001$ & $\begin{array}{c}4.85 \\
(2.62-8.98) \\
\end{array}$ & $<0.001$ & $\begin{array}{c}15.75 \\
(5.96-41.62) \\
\end{array}$ \\
\hline Short neck & $<0.001$ & $\begin{array}{c}5.27 \\
(2.91-9.54) \\
\end{array}$ & $<0.001$ & $\begin{array}{c}3.93 \\
(2.19-7.03) \\
\end{array}$ & $<0.001$ & $\begin{array}{c}10.39 \\
(4.29-25.13)\end{array}$ \\
\hline Absence of teeth & 0.008 & $\begin{array}{c}2.61 \\
(1.27-5.33) \\
\end{array}$ & 0.5 & $\begin{array}{c}0.77 \\
(0.37-1.61) \\
\end{array}$ & 0.643 & $\begin{array}{c}1.34 \\
(0.38-4.68) \\
\end{array}$ \\
\hline Prosthesis & 0.81 & $\begin{array}{c}1.06 \\
(0.64-1.74)\end{array}$ & 0.25 & $\begin{array}{c}1.33 \\
(0.81-2.18)\end{array}$ & 0.664 & $\begin{array}{c}0.84 \\
(0.38-1.82)\end{array}$ \\
\hline Mallampati III or IV & 0.94 & $\begin{array}{c}1.02 \\
(0.51-2.02) \\
\end{array}$ & 0.84 & $\begin{array}{c}0.93 \\
(0.47-1.83) \\
\end{array}$ & 0.507 & $\begin{array}{c}0.68 \\
(0.22-2.08) \\
\end{array}$ \\
\hline Constant & 0.001 & 0.07 & 0.002 & 0.095 & 0.001 & 0.02 \\
\hline
\end{tabular}

$\mathrm{BMI}=$ body mass index; $\mathrm{DMV}=$ difficult mask ventilation; $\mathrm{DL}=$ difficult laryngoscopy $; \mathrm{OR}=$ odds ratio $; 95 \% \mathrm{CI}=95 \%$ confidence interval

tions. The reason for not having identified the effect of the degree of obesity on difficult airway management may be the unstable distribution of patients in our cohort. This limitation could restrict accessible parameters for uniformity and statistical evaluation. There are many reports examining airway conditions in adult obese patients, however, our report is unique for being the first that was solely focused on endometrial cancer patients.
In conclusion, this study demonstrated that LNM and $\mathrm{SN}$ appeared to be the major risk factors for developing DMV and/or DL in endometrial cancer patients. Although all our patients were obese, the present study failed to identify the correlation between the increase in BMI and difficult airway management. Further studies are needed to demonstrate such a relation for better understanding of the role of obesity on this challenging clinical entity. 


\section{Acknowledgment}

This study was supported by the Baskent University Research Fund.

\section{References}

1. Davoodi SH, Malek-Shahabi T, Malekshahi-Moghadam A, Shahbazi R, Esmaeili S. Obesity as an important risk factor for certain types of cancer. Iran J Cancer Prev. 2013;6(4):18694.

2. World Health Organization. Obesity and overweight. [Internet] Updated January 2015. Available from: http://www.who. int/mediacentre/factsheets/fs311/en/.

3. Kheterpal S, Healy D, Aziz MF, Shanks AM, Freundlich RE, Linton F, Martin LD, Linton J, Epps JL, FernandezBustamante A, Jameson LC, Tremper T, Tremper KK; Multicenter Perioperative Outcomes Group (MPOG) Perioperative Clinical Research Committee. Incidence, predictors, and outcome of difficult mask ventilation combined with difficult laryngoscopy: a report from the multicenter perioperative outcomes group. Anesthesiology. 2013;119(6):1360-9. doi: 10.1097/ALN.0000435832.39353.20

4. Cook TM, MacDougall-Davis SR. Complications and failure of airway management. Br J Anaesth. 2012;109 Suppl 1:i68-i85. doi: 10.1093/bja/aes393

5. Kuku S, Dick J, Olaitan A. The surgical management of morbidly obese women with endometrial cancer. Health. 2012;4(12A):1442-7. doi: 10.4236/health.2012.412A208

6. Abu-Abid S, Szold A, Klausner J. Obesity and cancer. J Med. 2002;33(1-4):73-86.

7. De Jong A, Molinari N, Pouzeratte Y, Verzilli D, Chanques G, Jung B, Futier E, Perrigault PF, Colson P, Capdevila X,
Jaber S. Difficult intubation in obese patients: incidence, risk factors, and complications in the operating theatre and in intensive care units. Br J Anaesth. 2015;114(2):297-306. doi: 10.1093/bja/aeu373

8. Shailaja S, Nichelle SM, Shetty AK, Hegde BR. Comparing ease of intubation in obese and lean patients using intubation difficulty scale. Anesth Essays Res. 2014;8(2):168-74. doi: 10.4103/0259-1162.134493

9. Samsoon GL, Young JR. Difficult tracheal intubation: a retrospective study. Anaesthesia. 1987;42(5):487-90. doi:10.1016/0278-2391(87)90255-2

10. Han R, Tremper KK, Kheterpal S, O'Reilly M. Grading scale for mask ventilation. Anesthesiology. 2004;101(1):267.

11. Cormack RS, Lehane J. Difficult tracheal intubation in obstetrics. Anaesthesia. 1984;39(11):1105-11. doi: 10.1111/ j.1365-2044.1984.tb08932.x

12. El-Orbany M, Woehlck HJ. Difficult mask ventilation. Anesth Analg. 2009;109(6):1870-80. doi: 10.1213/ ANE.0b013e3181b5881c

13. Langeron O, Masso E, Huraux C, Guggiari M, Bianchi A, Coriat P, Riou B. Prediction of difficult mask ventilation. Anesthesiology. 2000;92(5):1229-36.

14. Yildiz TS, Solak M, Toker K. The incidence and risk factors of difficult mask ventilation. J Anesth. 2005;19(1):7-11. doi: 10.1007/s00540-004-0275-z

15. Lundstrom LH, Moller AM, Rosenstock C, Astrup G, Wetterslev J. High body mass index is a weak predictor for difficult and failed tracheal intubation: a cohort study of 91,332 consecutive patients scheduled for direct laryngoscopy registered in the Danish Anesthesia Database. Anesthesiology. 2009;110(2):266-74. doi: 10.1097/ALN.0b013e318194cac8

\title{
Sažetak \\ PROCJENA I LIJEČENJE OTEŽANOG DIŠNOG PUTA KOD PRETILIH BOLESNICA: RETROSPEKTIVNO ISTRAŽIVANJE U JEDNOM CENTRU
}

\author{
A. Ayhan, S. Kaplan, Z. Kayhan i G. Arslan
}

Primarni cilj ovoga retrospektivnog istraživanja provedenog u jednom centru bila je procjena otežane ventilacije maskom $(\mathrm{OVM})$ i otežane laringoskopije $(\mathrm{OL})$ u specifičnoj populaciji pretilih bolesnica. U istraživanje je bilo uključeno 427 odraslih bolesnica s indeksom tjelesne mase (ITM) >25 koje su kirurški liječene zbog karcinoma endometrija od 2011. do 2014. godine. Dodatno su bilježeni utjecaj porasta ITM, pridruženih bolesti, čimbenika rizika određenih kliničkim probirnim testovima i alata kojim su se zbrinjavale bolesnice na OVM i/ili OL. Svaka eskalacija u broju rizičnih čimbenika je povećavala rizik OVM za 2,2 puta, OL 1,8 puta i OVM+OL 3,0 puta. Od kliničkih testova, ograničena pokretljivost vrata $(\mathrm{OPV})$, kratak vrat $(\mathrm{KV})$ i nedostatak zuba su bili značajni za OVM $(\mathrm{p}<0,05), \mathrm{OPV}, \mathrm{KV}$ i opstruktivna bolest spavanja za OL $(p<0,05)$ te OPV i KV za OVM+OL ( $<<0,05)$. Međutim, kad su razmatrane bolesnice $s$ ITM $>25$, tada deseterostruki porast nije bio nezavisni rizični čimbenik. Zaključno, OPV i KV su nezavisni čimbenici rizika za razvoj OVM i/ili OL u pretilih bolesnica s karcinomom endmetrija, dok ITM veći od 30 nije dodatno uticao na otežani dišni put.

Ključne riječi: Dišni put, zbrinjavanje; Dišni put, opstrukcija; Intubacija, intratrachealna; Laringoskopija; Karcinom endometrija-kirurgija; Anestezija, opća; Pretilost; 